\title{
FACTORS INFLUENCING THE TAX MENTALITY OF AN AVERAGE TAXPAYER IN POLAND
}

\section{Dominika Florek}

PhD student, Wroclaw University of Economics and Business, Wroclaw, Poland

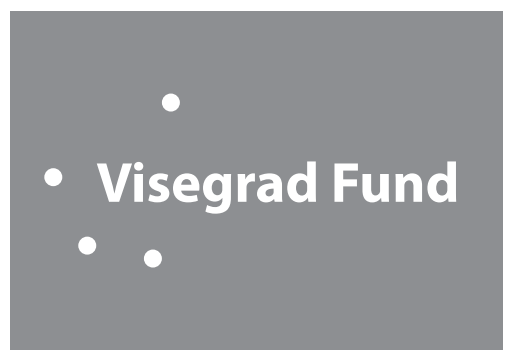

Correspondence:

Dominika Florek

e-mail:

florek.dominika22@gmail.com

\begin{abstract}
:
The main objective of the study was to evaluate the impact of specific elements of the tax environment upon the tax mentality of an average taxpaying natural person in Poland. For this purpose, the author identified four platforms for the analytical evaluation of tax compliance, namely: normative, organizational, economic, and psychological. The concept of tax mentality was defined, and followed by determination of factors that may potentially influence it. The study employed the following research methods: literature analyses and studies, statistical methods, thought experiment, diagnostic poll. The research problem was construed on the sound fundament of available sources and published research results, both domestic and foreign. The paper presents detailed analyses and conclusions derived from a pilot study designed and conducted by this author .
\end{abstract}

Keywords:

taxes, taxpayers, tax mentality, tax decisions, tax environment.

\section{INTRODUCTION}

A tax system is a constant element of daily human endeavours, globally. One cannot simply choose to abstain from paying their tax dues, as taxes represent an obligatory burden placed upon each and every taxpaying person. And since 'no one is patriotic about taxes', as aptly put by G. Orwell,the main objective of this study was to provide a careful analytical evaluation of factors that may influence the tax mentality of an average physical taxpaying person in Poland. Human behavioural patterns and habits may result in behaviours and attitudes which quite often defy logic or reason. In addition, taxpayers may choose to apply some of the legal methods of tax leniency vortex avoidance which are formally made available to them under the current legislation.

The main objective of this paper is to provide an evaluation of the impact exerted by factors representing the identified tax platforms upon tax mentality of an average taxpayer in Poland. The four tax platforms were identified on the basis of literature studies. This setting was then employed as a fundament for a pilot study intended to provide identifications of such factors of potential impact for each of thus defined categories of analysis. Replies from the respondent sample were then employed as basis for qualitative and quantitative analyses, together with examination of both the strength and direction of the identified correlations between factors. The subject of the study was defined to represent physical persons regulating their income tax obligations in Poland, while the object of research comprised of the current tax system in Poland, together with its internal and external environment, including the operation practices of those state institutions that directly affect the tax environment in Poland. 
The study employed a broad range of research methods, including literature analyses and studies, statistical methods, thought experiment, and diagnostic poll [Apanowicz, pp. $60-80]$. The research problem was defined on the basis of literature studies in the sphere of tax management as well as analyses and studies of factors impacting tax decisions, both domestic and foreign. The author of the paper assumes that in tax awareness there may be a beginning of the beginning. Where man extends transience in one area to another, it will also expand. It seems obvious that the $4^{\text {th }}$ Industrial Revolution will expect a higher level of awareness in every area.

\section{TAX PLATFORMS AND TAXPAYER MENTALITY}

Physical persons regulating their tax dues are naturally exposed (to a varied extent) to their national tax system and to some of its constituent elements. In an attempt at systematizing the wealth of notions associated with the tax environment, one may employ a classification by thematic area of their application. M. Poszwa postulates the following classification of tax aspects (referred to as platforms):

- normative;

- organizational;

- psychological;

- economic [Poszwa, 2008, pp. 15-17].

Subject literature provides examples of different terminology in use. For instance, P.M. Gaudemet utilizes a category of political area (in place of the psychological perspective) to integrate all the behavioural aspects of the studied problem [Gaudemet, 1990, p. 98]. Taking aside the above reservation, the normative platform represents the legal environment of a taxpaying physical person, including the national tax ordinance and all the detailed regulations applicable to specific forms of taxation. The organizational aspect is associated with the entirety of the state institutional taxation structure, including methods of operation available to state institutions as well as institutional personnel and their competences (both soft and hard). The psychological dimension is the most complex and compound group of aspects, influenced among other things by: taxpayers' subjective opinions, their emotions, historical or cultural determinants, and personal experiences with the tax system. Lastly, the economic platform comprises the entirety of the tax burden placed upon taxpayers, representing the ratio of cost to total assets held by them[Owsiak, 2017, pp. 253-259].

Decisions made by taxpayers are rooted in their preexisting mentality. Tax mentality itself strongly affects the perception of the tax system as a whole. In its dictionary definition (Słownik Języka Polskiego), the term 'mentality' represents a mindset that defines a certain person or social group in clear opposition to others. Following this line of reasoning, it may be assumed that each person or group has their own distinct mentality[https://sjp.pl/ mentalnosc]. Tax mentality represents an attitude taken by a person or a group towards their tax obligations. In the above sense, tax mentality should be influenced by numerous factors of external character, such as the political climate, legal structure and judicial system, general education, culture, and emotional intelligence or general level of awareness. Mentality is also shaped by state governance and formal communication of tax redistribution patterns and changes in fiscal legislation by state institutions [Gomułowicz and Mączyński, 2016, pp. 274-278].Lastly, tax mentality may also be strongly affected by ingrown personal attitudes and behaviours. Personal upbringing and early experiences may also shape the tax mentality of individuals at later stages in their lives.

The evolution (formation) of attitudes of individual persons towards their tax obligations is a complex process shaped by multiple factors. In view of the above, according to M. Pietrewicz, an average taxpayer may display some of the following six types of response to their tax obligations:

- tax compliance - full realization of one's tax obligations;

- tax shifting - transfer or redistribution of one's tax burden;

- seeking legal ways to evade tax obligations;

- price shifting to recover the cost of one's tax obligations;

- illegal evasion of one's tax obligations;

- withdrawal from economic operations burdened with tax.

Depending on the adopted model of response behaviour, taxpayers will adhere to their original decision and will be intent on full realization of their chosen strategy, as it best serves their primary purpose. Thus, satisfaction of taxpayers' internalized needs is a prime mover of their actions.Contrary to the classical economics, the volume of the expected economic benefits is not the only motive behind decisions made with regard to one's tax obligations. Taxpayers are also quite strongly influenced by factors of a decidedly more behavioural nature[Çiçek, 2019, pp. 223-244].

\section{STUDY PRESENTATION AND RESEARCH METHODOLOGY}

Pilot studies were the main instrument of choice for the realization of the study of relative strength of impact exerted by individual tax platforms and their constituents upon the tax mentality of respondent base. The base included 92 respondents - students of high education institutions in Poland. 
The pilot study was designed to test the practical development of the postulated research problem. This form of a diagnostic poll can also be used for testing and evaluating the adequacy of the instrument selected for the task. Analyses of responses may be used to ascertain the need for further exploration of the subject under study [Nowak 2007, s. 59].

Respondents participating in the diagnostic poll were asked to present their opinions in a set of 32 queries, segmented into three categories. The first category was designed to form a statistical profile of the respondents, including age, place of birth, university, and field of study. The second category included queries of tax preferences, such as the preferred volume of tax obligations or their attitudes towards taxation in general. The last group of queries took the form of statements to be evaluated by respondents on a 5-degree scale, as follows:

- $\quad 1:$ strongly disagree;

- $\quad$ 2: partly disagree;

- 3: no opinion/I don't know;

- $\quad$ 4: partly agree;

- 5: fully agree.

In addition, statements in the last category were further separated into groups by tax platform they refer to. At the same time, statements were presented in a random sequence, to make sure that the respondents would be fairly unaware of the separation adopted for our purpose.

Responses to the pilot study poll were collected between March 10th and April 26th, 2020. The time frame coincided with the COVID-19 pandemic outburst. In effect, it may be assumed that the responses would be, to some extent, influenced by governmental strategies employed in response to the pandemic threat. At the time of the poll, the Polish government offered formal support for various tax and unemployment alleviation policies, such as a 3-month social insurance premium relief for entrepreneurs affected by the crisis or the surplus family allowance for persons forced to stay at home to take care of their children up to the age of 8 [The Act ... of March 2, 2020 r.].

\section{DEMOGRAPHICS OF THE RESEARCH SAMPLE}

The research sample established for the purpose of the pilot study included 92 respondents - students of high education institutions in Poland. The group was populated by $57.61 \%$ female and $42.39 \%$ male respondents. Of all the persons included in the study, $71.83 \%$ were between 22 and 24 years of age. Strong representation of $16.30 \%$ was recorded of persons in the age segment of 18 to 21 . The least populated group was that of persons past the age of 29. Chart 1 presents percentage shares of all age groups included in the pilot study.

Chart 1. A percentage distribution of respondents by age group

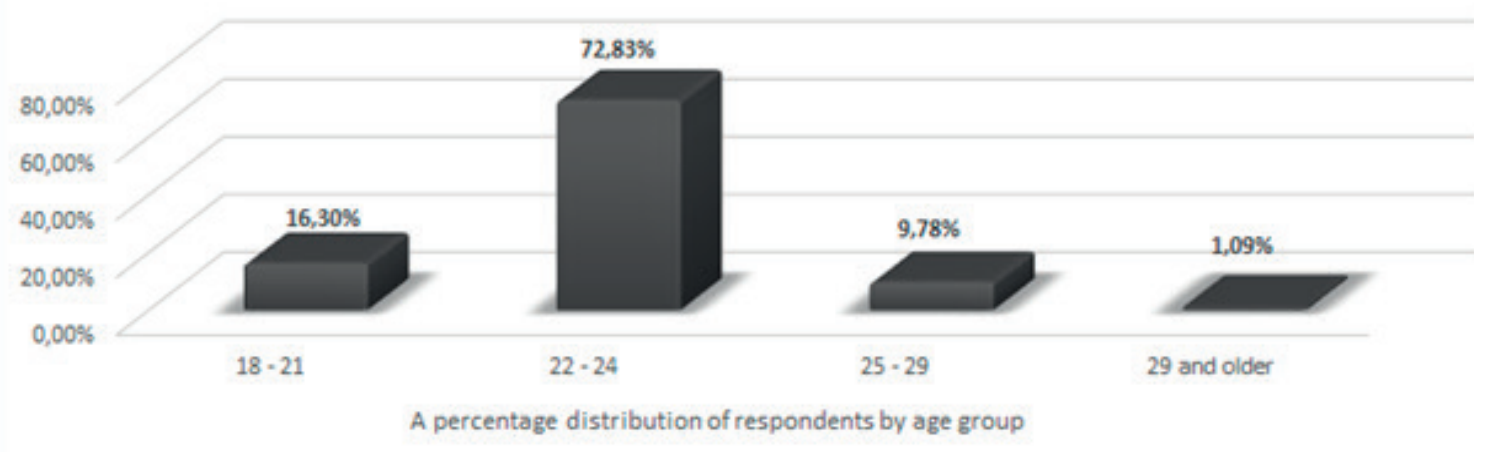

Source: own research based on responses collected in the pilot study

A strong share of $63.04 \%$ of respondents reported their status as 'combining work with studies', with $27.17 \%$ reporting their work obligations in a full-time employment regime.
In contrast to the above, $35.87 \%$ of all respondents described their status as students with part-time employment. Chart 2 presents the distribution of respondent sample by employment status. 
Chart 2. A percentage distribution of respondents by employment status

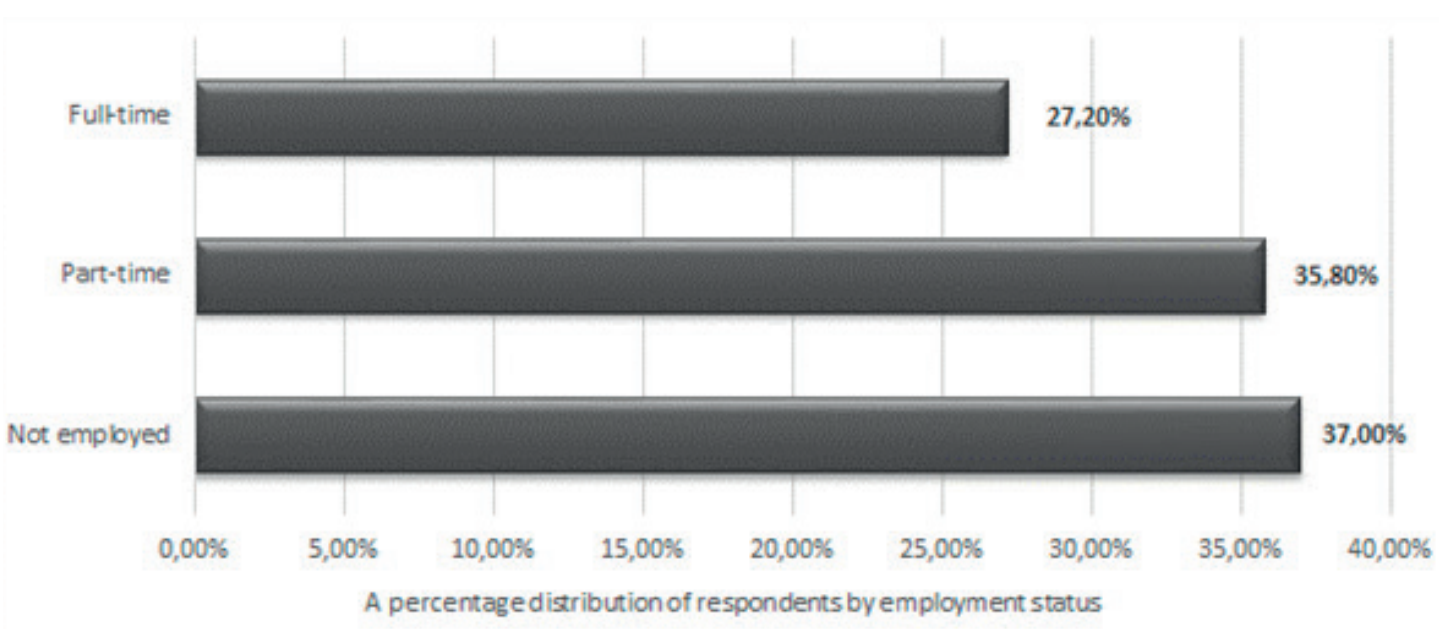

Source: own research based on responses collected in the pilot study

$71.74 \%$ of all respondents defined themselves at the time of the poll as students of Wroclaw University of Economics and Business. The second most populated group was that of students at Wroclaw Technical University, representing $6.52 \%$ of the respondent sample. In total, the poll was attended by students of 14 separate institutions of higher learning; see Chart 3 for details in this respect.

Chart 3. A percentage distribution of respondents by university

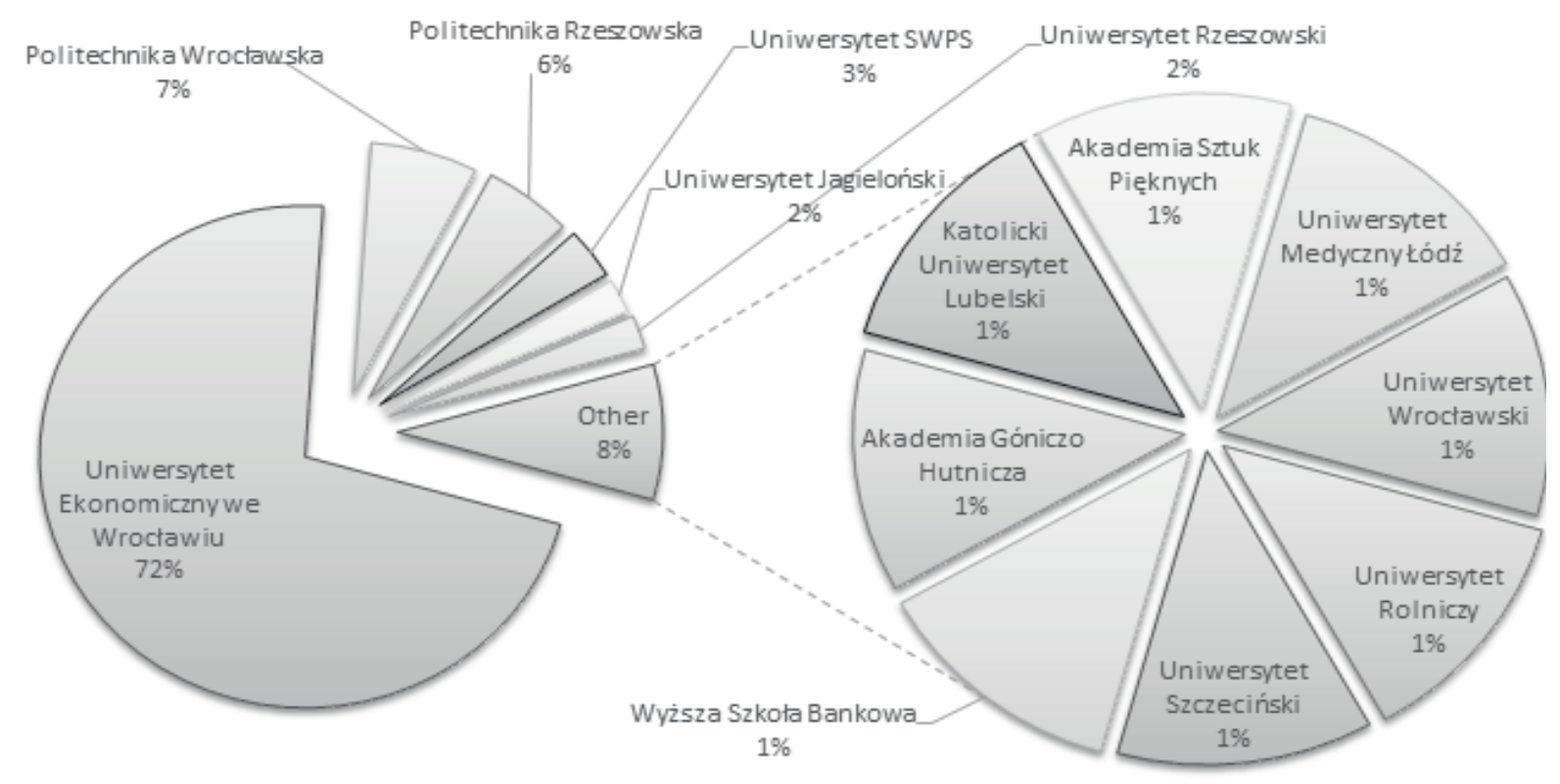

Source: own research based on responses collected in the pilot study

For reasons dictated by the precautionary measures introduced by the global COVID-19 pandemic, the pilot study was conducted using Google Forms, a free online survey service.

\section{ANALYSIS AND EVALUATION OF THE POLL RESULTS}

Analysis of responses to the pilot study poll were conducted with the use of descriptive and mathematic methods. Responses of all participants were presented in relation to the four identified platforms of tax environment, 
in the form of percentage shares. Table 1 presents details of the adopted 5-scale evaluation collected in relation to statements representative of the normative platform. Of all the respondents, $72.83 \%$ were firmly $(40.22 \%)$ or moderately adamant $(32.22 \%)$ that the Polish system supports an excessive number of taxation variants. In addition, $85.87 \%$ of the respondents attached a ranking of five (36.96\%) or four (48.91\%) to the statement that The Polish tax system places uneven burden on various social or vocational groups. Respondents in our diagnostic poll were partly $(31.52 \%)$ or wholly opposed to the view $(30.43 \%)$ that The Polish tax system offers adequate protection of low-income persons. Lastly, $80.43 \%$ of the respondents subscribed to the need for such solutions as tax reliefs, tax deductions and deductions from taxable income.

Table 1. A percentage distribution of poll responses associated with the normative platform

\begin{tabular}{cccccc}
\hline $\begin{array}{c}\text { I strongly } \\
\text { disagree }\end{array}$ & $\begin{array}{c}\text { I partly } \\
\text { disagree }\end{array}$ & $\begin{array}{c}\text { I don't } \\
\text { know }\end{array}$ & $\begin{array}{c}\text { I partly } \\
\text { agree }\end{array}$ & $\begin{array}{c}\text { I fully } \\
\text { agree }\end{array}$ & Statement \\
\hline $2.17 \%$ & $13.04 \%$ & $11.96 \%$ & $32.61 \%$ & $40.22 \%$ & $\begin{array}{l}\text { The Polish tax system support an excessive number of taxation } \\
\text { variants. }\end{array}$ \\
\hline $10.87 \%$ & $19.57 \%$ & $35.87 \%$ & $28.26 \%$ & $5.43 \%$ & $\begin{array}{l}\text { The Polish tax system offers preferences for the financially } \\
\text { excluded and for those in (transitory) financial distress. }\end{array}$ \\
\hline $30.43 \%$ & $31.52 \%$ & $21.74 \%$ & $13.04 \%$ & $3.26 \%$ & $\begin{array}{l}\text { The Polish tax system offers sdequate protection of low- } \\
\text { income persons. }\end{array}$ \\
\hline
\end{tabular}

Source: own research based on responses collected in the pilot study

The next platform subject to analytical evaluation was the psychological platform. Table 2 presents a percentage distribution of responses in this section. The statement that The tax system in Poland is fair and just was strongly opposed by $29.30 \%$ and partly opposed by further $42.39 \%$ of respondents. As much as $88.04 \%$ were found to partly $(28.26 \%)$ or strongly $(59.78 \%)$ reject the statement that The state is effective in managing their budgetary income from tax receipts.

Table 2. A percentage distribution of poll responses associated with the psychological platform

\begin{tabular}{|c|c|c|c|c|c|c|}
\hline \multirow{7}{*}{ 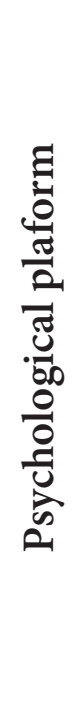 } & $\begin{array}{l}\text { I strongly } \\
\text { disagree }\end{array}$ & $\begin{array}{l}\text { I partly } \\
\text { disagree }\end{array}$ & $\begin{array}{l}\text { I don't } \\
\text { know }\end{array}$ & $\begin{array}{l}\text { I partly } \\
\text { agree }\end{array}$ & $\begin{array}{l}\text { I fully } \\
\text { agree }\end{array}$ & Statement \\
\hline & $29.35 \%$ & $42.39 \%$ & $17.39 \%$ & $10.87 \%$ & $0.00 \%$ & The tax system in Poland is fair and just. \\
\hline & $9.78 \%$ & $6.52 \%$ & $13.04 \%$ & $33.70 \%$ & $36.96 \%$ & $\begin{array}{l}\text { The tax policy in Poland is a direct produst of the curtent } \\
\text { political agenda supported by the governing party. }\end{array}$ \\
\hline & $59.78 \%$ & $28.26 \%$ & $8.70 \%$ & $2.17 \%$ & $1.09 \%$ & $\begin{array}{l}\text { The state is sffective in managing their budgetary income } \\
\text { from tax receipts. }\end{array}$ \\
\hline & $17.39 \%$ & $20.65 \%$ & $19.57 \%$ & $17.39 \%$ & $25.00 \%$ & $\begin{array}{l}\text { Given a choice in the matter, I would gladly abstain from } \\
\text { paying my tax dues. }\end{array}$ \\
\hline & $39.13 \%$ & $25.00 \%$ & $18.48 \%$ & $9.78 \%$ & $7.61 \%$ & $\begin{array}{l}\text { Withholding parts of formal inome for tax benefit purposes } \\
\text { can be seen as a manifestation of resourcefulness. }\end{array}$ \\
\hline & $6.52 \%$ & $16.30 \%$ & $11.96 \%$ & $29.35 \%$ & $35.87 \%$ & $\begin{array}{l}\text { Exploting various gaps and loopholes in the tax law is a } \\
\text { commenddable behaviour. }\end{array}$ \\
\hline
\end{tabular}

Source: own research based on responses collected in the pilot study 
The next platform under consideration was the economic one. Table 3 presents a percentage distribution of responses in this segment. A total of $76.09 \%$ of the pilot study respondents subscribed to the view that Taxes in Poland should be lower (with full support from 56.52\%ful- ly, and partial support from 19.57\%). The statement that Tax dues paid by high-income persons are in fair proportion to their gains was supported by $64.13 \%$ of respondents (43.48\%and $20.65 \%$, respectively).

Table 3. A percentage distribution of poll responses associated with the economic platform

\begin{tabular}{ccccccl}
\hline & $\begin{array}{c}\text { I strongly } \\
\text { disagree }\end{array}$ & $\begin{array}{c}\text { I partly } \\
\text { disagree }\end{array}$ & $\begin{array}{c}\text { I don't } \\
\text { know }\end{array}$ & $\begin{array}{c}\text { I partly } \\
\text { agree }\end{array}$ & $\begin{array}{c}\text { I fully } \\
\text { agree }\end{array}$ & Statement \\
\cline { 2 - 6 } & $19.57 \%$ & $19.57 \%$ & $13.0 \% 4$ & $25.00 \%$ & $22.83 \%$ & $\begin{array}{l}\text { Tax dues should be calculed at a constant ratio, regardless } \\
\text { of the reported income.. }\end{array}$ \\
\cline { 2 - 6 } & $9.78 \%$ & $16.30 \%$ & $9.78 \%$ & $20.65 \%$ & $43.48 \%$ & $\begin{array}{l}\text { Tax dues paid by high-income persons are in fair propotrion } \\
\text { to their gains. }\end{array}$ \\
\hline $3.26 .26 \%$ & $18.48 \%$ & $19.57 \%$ & $23.91 \%$ & $9.78 \%$ & $\begin{array}{l}\text { Selected social and vocational groups should enjoy a range } \\
\text { of tax privileges. }\end{array}$ \\
\hline
\end{tabular}

Source: own research based on responses collected in the pilot study

The organizational platform of our tax analysis included five statements, see Table 4 for a detailed structure of responses. A total of $79.35 \%$ of respondents recognized taxes as one of the major barriers to business entry in Poland (57.61\% fully, and $21.74 \%$ partly). An interesting structure of responses was observed with relation to the following:
During my tax office visits, I typically have the satisfaction of being served by competent personnel. As much as $42.39 \%$ of respondents chose to select the 'I don't know' response, which may be evidence of their fairly limited experience in this context, with the majority of respondents still in their student years.

Table 4. A percentage distribution of poll responses associated with the organizational platform

\begin{tabular}{|c|c|c|c|c|c|c|}
\hline \multirow{6}{*}{ 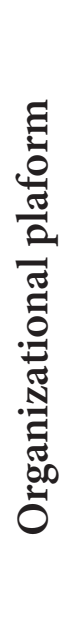 } & $\begin{array}{l}\text { I strongly } \\
\text { disagree }\end{array}$ & $\begin{array}{l}\text { I partly } \\
\text { disagree }\end{array}$ & $\begin{array}{l}\text { I don't } \\
\text { know }\end{array}$ & $\begin{array}{l}\text { I partly } \\
\text { agree }\end{array}$ & $\begin{array}{l}\text { I fully } \\
\text { agree }\end{array}$ & Statement \\
\hline & $10.87 \%$ & $21.74 \%$ & $42.29 \%$ & $16.30 \%$ & $8.70 \%$ & $\begin{array}{l}\text { Suring my tax office visits, I have the statifaction of being } \\
\text { served by competent personnel. }\end{array}$ \\
\hline & $10.87 \%$ & $29.35 \%$ & $27.17 \%$ & $26.09 \%$ & $6.52 \%$ & $\begin{array}{l}\text { Fiscal suthorities and institutions provide sufficient information } \\
\text { and support for reporting purposes. }\end{array}$ \\
\hline & $11.96 \%$ & $16.30 \%$ & $34.78 \%$ & $31.52 \%$ & $5.43 \%$ & $\begin{array}{l}\text { My experences with tax office perssonel have largely been } \\
\text { positive. }\end{array}$ \\
\hline & $8.70 \%$ & $5.43 \%$ & $13.04 \%$ & $34.78 \%$ & $38.04 \%$ & $\begin{array}{l}\text { I understand and recognize the state mechanisam of financing } \\
\text { public services. }\end{array}$ \\
\hline & $0.00 \%$ & $8.70 \%$ & $11.96 \%$ & $21.74 \%$ & $57.61 \%$ & $\begin{array}{l}\text { Taxes are one of the major barriers to business entry in } \\
\text { Poland. }\end{array}$ \\
\hline
\end{tabular}

Source: own research based on responses collected in the pilot study

In one of the queries, respondents were asked for their preferences in effective income tax burden expected of them; for detailed distribution, see Chart 4 below. A sizeable $45.65 \%$ of respondents chose the $1-10 \%$ range of effective tax rate. 


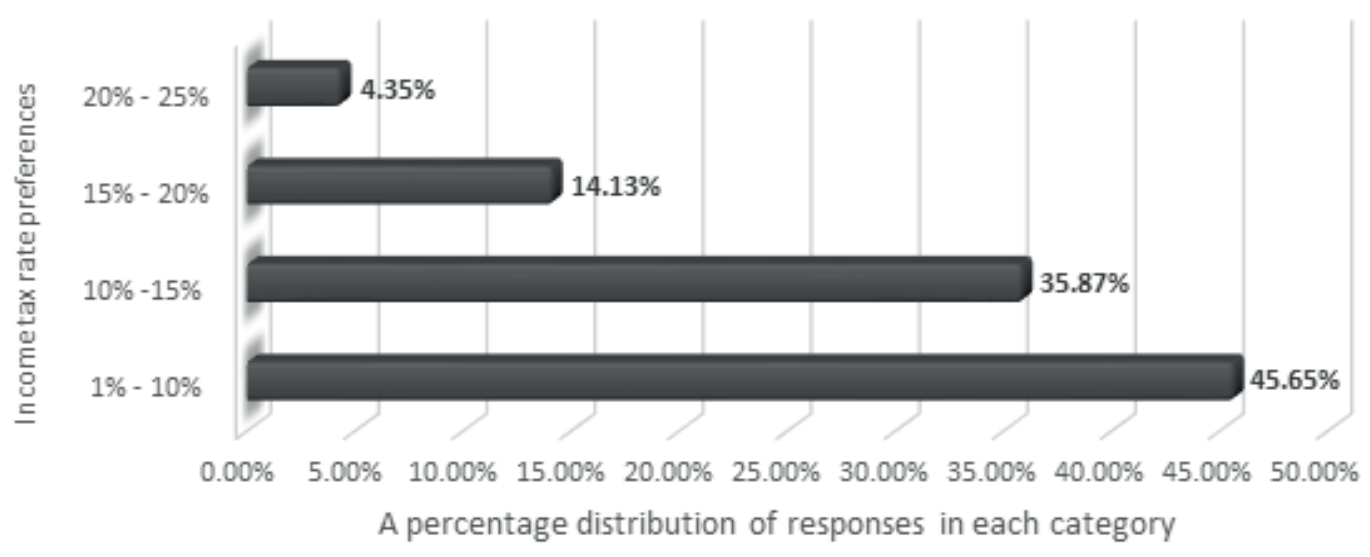

Source: own research based on responses collected in the pilot study

Our analytical evaluation included the examination of responses to the query of preferred tax rate in relation to the reported employment status (full employment, part-time employment, and no employment; see the relevant charts below for detailed distributions. As many as 12 of the respondents who report combining their studies with full-time employment (48\%) were found to subscribe to the view that their income tax should not exceed the $10 \%$ threshold.

Chart 6 presents the preferred income tax rates among students with part-time employment. Again, a sound $42.42 \%$ showed preferences for the 1-10\% threshold.

Chart 5. Tax rate preferences among students with full-time employment

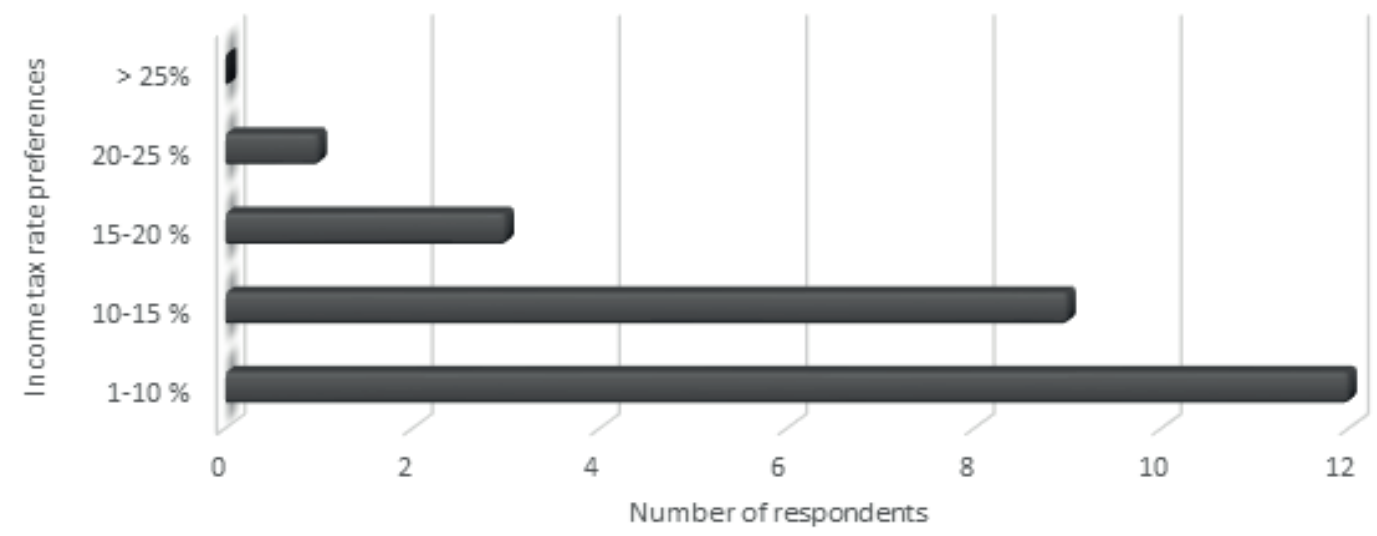

Source: own research based on responses collected in the pilot study

Chart 6. Tax rate preferences among students with part-time employment

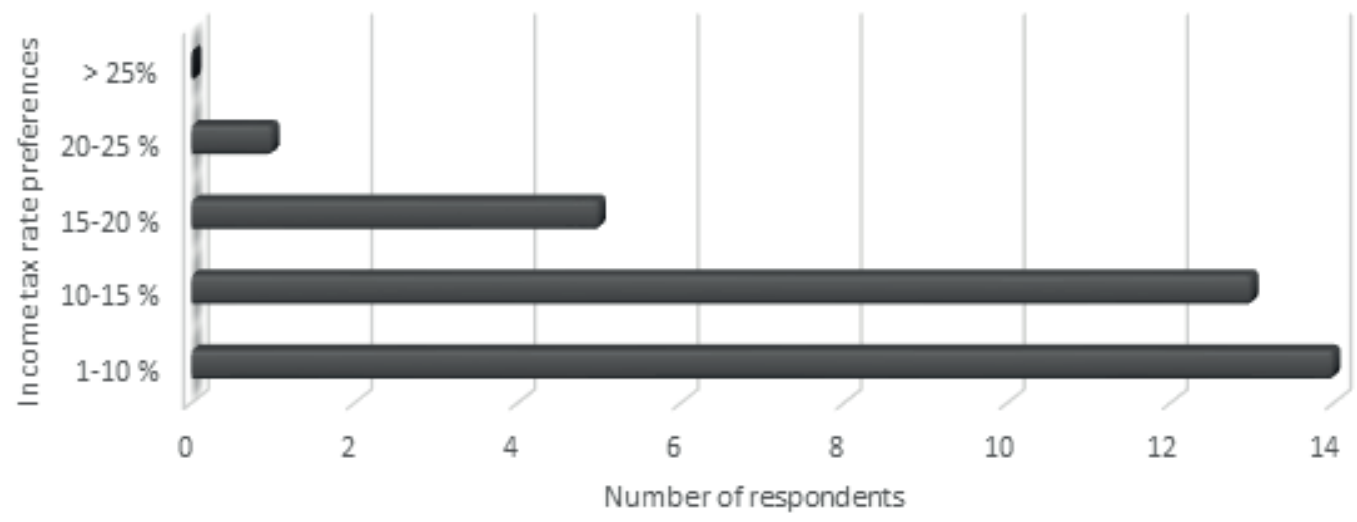

Source: own research based on responses collected in the pilot study 
Lastly, Chart 7 presents the preferred income tax rates among non-employed students. Once more, a sound $47.06 \%$ of respondents in this segment chose the $1-10 \%$ threshold as the most optimal sum they were willing to pass on to the public purse.

Chart 7. Tax rate preferences among students with no employment

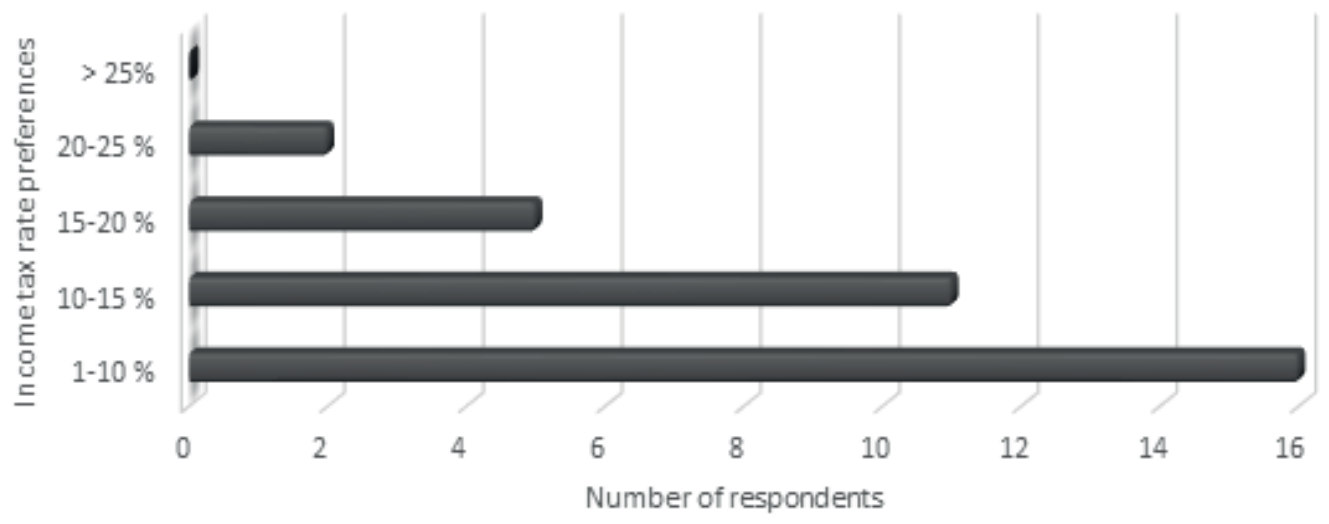

Source: own research based on responses collected in the pilot study

Analytical evaluation was also employed to examine the respondents' willingness to regulate their tax obligation from the gender perspective. For this purpose, the participants were asked to make their choice between upholding and abstaining from paying taxes if such a choice would ever be offered for their consideration. Chart 8 presents the structure of responses in this context: in such an imaginary scenario, $81.13 \%$ of women would be willing to keep paying their taxes; for men, the ratio was lower by a sound value of 22.43 percentage points, and amounted to $58.97 \%$.

Chart 8. A percentage distribution of respondents by gender with regard to their disclosed willingness to pay taxes

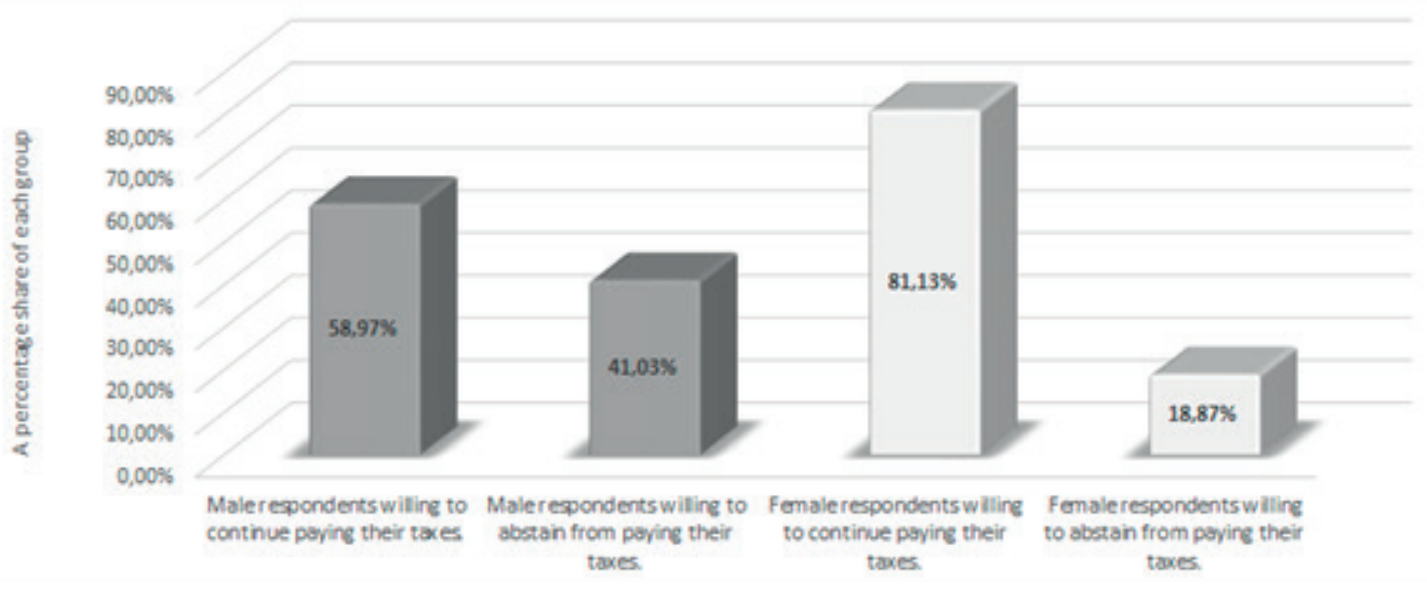

Source: own research based on responses collected in the pilot study

Matrix 1 presents correlations observed between all the 32 variables identified over the course of the pilot study. Correlations in excess of $40 \%$ are marked in yellow, while green is used to signify elements described by correlations in excess of $50 \%$. Correlations between variables were calculated using a standard Pearson function (Microsoft Excel).
Table 5 presents descriptions of the variables included in linear correlation analyses. Some of the variables required standardization to make them comparable with the remaining set. 
Matrix 1. Linear correlations between the standardized variables

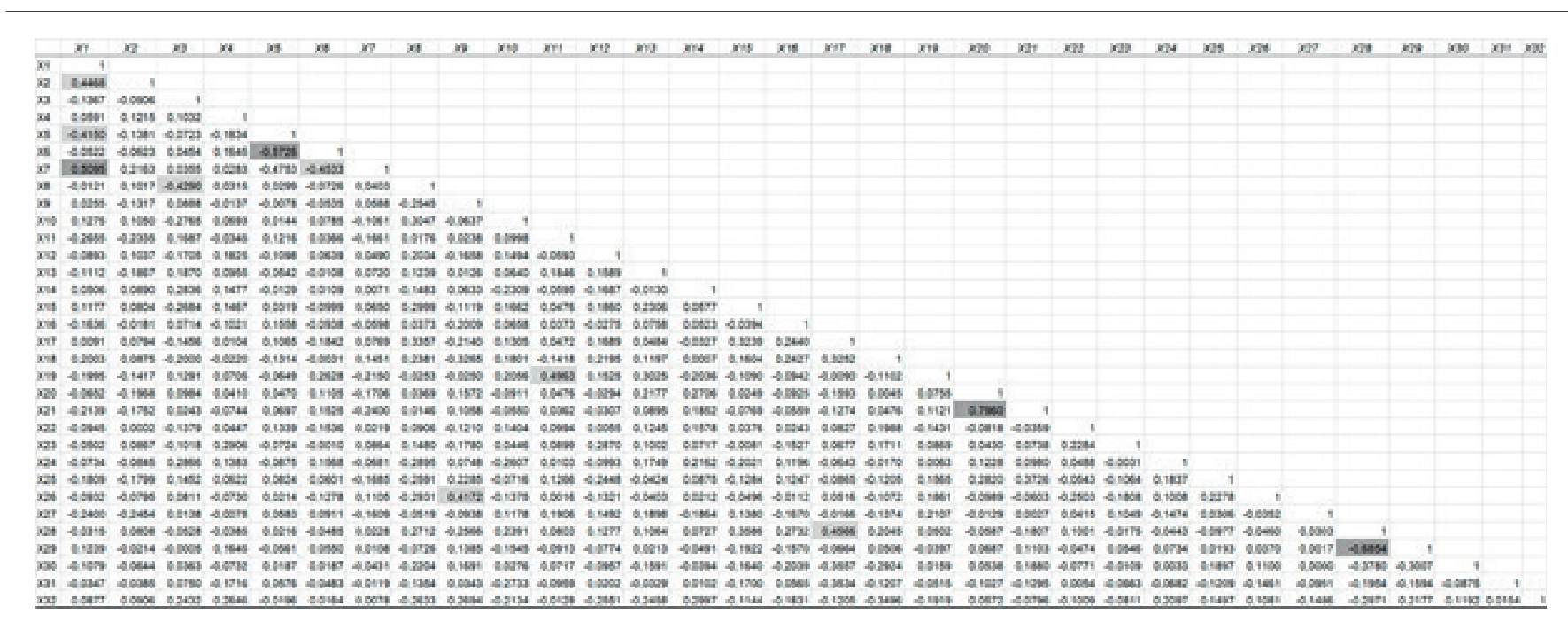

Source: own research based on responses collected in the pilot study

Table 5. Descriptions of variables examined by linear correlation analyses, as shown in Matrix 1.

\begin{tabular}{|c|c|c|c|}
\hline Variable & Description & Variable & Description \\
\hline $\mathrm{X} 1$ & Average monthly income over the last year. & \multirow[b]{2}{*}{ X19 } & \multirow[b]{2}{*}{$\begin{array}{l}\text { Opinion on the statement: The Polish tax system } \\
\text { offers adequate protection of low-income persons. }\end{array}$} \\
\hline $\mathrm{X} 2$ & $\begin{array}{l}\text { The value of personal income tax paid for the last } \\
\text { reporting year (as reported in the PIT form). }\end{array}$ & & \\
\hline $\mathrm{X} 3$ & Gender & \multirow{3}{*}{$\mathrm{X} 20$} & \multirow{3}{*}{$\begin{array}{l}\text { Opinion on the statement: My experiences with tax } \\
\text { office personnel have largely been positive. }\end{array}$} \\
\hline $\mathrm{X} 4$ & Year of studies & & \\
\hline $\mathrm{X} 5$ & Vocational status: unemployed & & \\
\hline X6 & Vocational status: part-time employment & \multirow{2}{*}{$\mathrm{X} 21$} & \multirow{2}{*}{$\begin{array}{l}\text { Opinion on the statement: During my tax office } \\
\text { visits, I have the satisfaction of being served by } \\
\text { competent personnel. }\end{array}$} \\
\hline $\mathrm{X} 7$ & Vocational status: full-time employment & & \\
\hline $\mathrm{X} 8$ & $\begin{array}{l}\text { Opinion on the statement: The Polish tax system } \\
\text { supports an excessive number of taxation variants }\end{array}$ & $\mathrm{X} 22$ & $\begin{array}{l}\text { Opinion on the statement: Exploitingvarious gaps } \\
\text { and loopholes in the tax law is a commendable } \\
\text { behaviour. }\end{array}$ \\
\hline X9 & $\begin{array}{l}\text { Opinion on the statement: The tax system in } \\
\text { Poland is fair and just. }\end{array}$ & $\mathrm{X} 23$ & $\begin{array}{l}\text { Opinion on the statement:I understand and recognize } \\
\text { the state mechanism of financing public services. }\end{array}$ \\
\hline $\mathrm{X} 10$ & $\begin{array}{l}\text { Opinion on the statement: Tax dues should be } \\
\text { calculated at a constant ratio, regardless of the } \\
\text { reported income. }\end{array}$ & $\mathrm{X} 24$ & $\begin{array}{l}\text { Opinion on the statement:Selected social and vocation- } \\
\text { al groups should enjoy a range of tax privileges. }\end{array}$ \\
\hline $\mathrm{X} 11$ & $\begin{array}{l}\text { Opinion on the statement:The Polish tax system } \\
\text { offers preferences for the financially excluded and } \\
\text { for those in (transitory) financial distress. }\end{array}$ & $\mathrm{X} 25$ & $\begin{array}{l}\text { Opinion on the statement:Fiscal authorities and } \\
\text { institutions provide sufficient information and } \\
\text { support for reporting purposes. }\end{array}$ \\
\hline $\mathrm{X} 12$ & $\begin{array}{l}\text { Opinion on the statement: The Polish tax system } \\
\text { places uneven burden on various social or } \\
\text { vocational groups. }\end{array}$ & $\mathrm{X} 26$ & $\begin{array}{l}\text { Opinion on the statement:The state is effective } \\
\text { in managing their budgetary income from tax } \\
\text { receipts. }\end{array}$ \\
\hline $\mathrm{X} 13$ & $\begin{array}{l}\text { Opinion on the statement:Tax dues paid by } \\
\text { high-income persons are in fair proportion to their } \\
\text { gains. }\end{array}$ & $\mathrm{X} 27$ & $\begin{array}{l}\text { Opinion on the statement:The tax policy in Poland } \\
\text { is a direct product of the current political agenda } \\
\text { supported by the governing party. }\end{array}$ \\
\hline $\mathrm{X} 14$ & $\begin{array}{l}\text { Opinion on the statement:Tax credits and other } \\
\text { tax and income deductions are needed. }\end{array}$ & $\mathrm{X} 28$ & Preferred value of personal income tax rate: $1 \%-10 \%$ \\
\hline $\mathrm{X} 15$ & $\begin{array}{l}\text { Opinion on the statement: Taxes are one of the } \\
\text { major barriers to business entry in Poland. }\end{array}$ & $\mathrm{X} 29$ & Preferred value of personal income tax rate : $10 \%-15 \%$ \\
\hline $\mathrm{X} 16$ & $\begin{array}{l}\text { Opinion on the statement:Given a choice in the matter, } \\
\text { I would gladly abstain from paying my tax dues. }\end{array}$ & $\mathrm{X} 30$ & Preferred value of personal income tax rate : $15 \%-20 \%$ \\
\hline $\mathrm{X} 17$ & $\begin{array}{l}\text { Opinion on the statement:Taxes in Poland should } \\
\text { be lower. }\end{array}$ & $\mathrm{X} 31$ & Preferred value of personal income tax rate : $20 \%-25 \%$ \\
\hline $\mathrm{X} 18$ & $\begin{array}{l}\text { Opinion on the statement:Withholding parts of } \\
\text { formal income for tax benefit purposes can be seen } \\
\text { as a manifestation of resourcefulness. }\end{array}$ & $\mathrm{X} 32$ & $\begin{array}{l}\text { Response to the question: - If you ever had a choice } \\
\text { between paying taxes and enjoying full benefits of } \\
\text { public services or not paying taxes and resigning from } \\
\text { the free use of public services (i.e. healthcare, education, } \\
\text { police, armed forces, fire service, public roads, etc.), } \\
\text { would you still be willing to pay your taxes? [YES/NO] }\end{array}$ \\
\hline
\end{tabular}


The highest correlation was found between variables $\mathrm{X} 20$ and X21, at 79.6\%. It means that the more positive the experiences from contact with tax office personnel were, the more satisfied the respondents with the competence of tax office staff were. Responses to variables X11 and X19 are correlated at the level of $46.91 \%$, meaning that participants willing to admit that the tax system in Poland places uneven burden on various groups were also more inclined to agree with the statement that the tax system in Poland offers adequate protection of low-income persons.

\section{CONCLUSIONS}

The study represents an attempt at evaluating the impact of various factors belonging to four main tax platforms (normative, organizational, psychological, and economic) upon tax mentality of individual taxpayers (physical persons) in Poland. For the purpose, the author employed a diagnostic tool in the form of an opinion poll. Based on responses collected during the pilot study, it may be assumed that tax mentality in Poland is subject to such impact, and evidenced in such aspects as: operation of state institutions, competences of tax office personnel, adjustment with current governmental policy, civic awareness level, and personal opinions of individual taxpayers. Each of the identified variables does exert a stronger or lesser impact on tax morality, providing grounds for further exploration. The evaluation of tax mentality in Poland was then related to the nature of the identified correlations - their strength and direction.

The findings produced by analytical evaluations will be employed as basis for advanced studies of the subject at hand. Further editions of the poll may be addressed to larger populations, to include respondents in a broader age spectrum and with different social or vocational background. Analyses of responses from such larger samples would require the use of more advanced instruments of data processing and analysis. Proper realization of the diagnostic poll on a larger scale would provide more informed input on the possible directions of further research.

\section{ACKNOWLEDGMENT}

This paper is part of the project No. 22010083 entitled "Experience sharing of Visegrad countries to tax avoid activity" financed by the International Visegrad Fund.

\section{LITERATURE}

Apanowicz J. (2002). Metodologia ogólna, Gdynia: Wydawnictwo Diecezji IV pelplińskiej „BERNARDINUM”.

Çiçek S., Güçlü Çiçek H., Şahin Ipek E.A. (2019). Behavioral Approach to Tax Compliance Process: Taxpayer Behaviors and Typologies. Sosyoekonomi Journal, Sosyoekonomi Society Issue 27(39).

Gaudemet P.M. (1990). Finanse publiczne. Warszawa: Polskie Wydawnictwo Ekonomiczne.

Gomułowicz A. Mączyński D. (2016). Podatki i prawo podatkowe. Warszawa: Wolters Kluwer.

Nowak S. (2007). Metodologia badań społecznych, Warszawa: Wydawnictwo Naukowe PWN.

Owsiak S. (2017). Finanse publiczne. Warszawa: Wydawnictwo Naukowe PWN.

Poszwa M. (2007). Zarządzanie podatkami w małej i średniej firmie. Warszawa: Wydawnictwo C.H. Beck.

Pietrewicz M. (1993). Polityka fiskalna, Warszawa: Wydawnictwo Poltext.

\section{Online sources:}

https://sjp.pl/mentalnosc (date of access: July 13, 2020).

\section{Legislation:}

The Act of March 2, 2020 on detailed solutions associated with prevention, containment and elimination of the COVID-19 virus and other infectious agents and on measures introduced to counteract their effects in crisis situations, Off.J. 2020, pos. 374. 